\title{
Pengaruh Model Pembelajaran Ditinjau dari Gaya Belajar terhadap Hasil Belajar Kelas VIII SMP Negeri 3 Gelumbang
}

\author{
Risa Rahmatia Firsta ${ }^{1}$, Mochammad Syahrul Azhar, Fita Khoirunnisa ${ }^{3}$ Ratu Ilma Indra Putri ${ }^{4}$ \\ Jeri Araiku ${ }^{5^{*}}$ Novita Sari ${ }^{6}$ \\ 1,4,5,6 Universitas Sriwijaya, Palembang, Sumatera Selatan 30139, Indonesia \\ 2,3 Universitas Pekalongan, Pekalongan, Jawa Tengah 51119, Indonesia
}

Pengiriman: 10/September/2021; Diterima: 24/September/2021; Publikasi: 30/September/2021

DOI: https://doi.org/10.31629/jg.v6i2.3954

\begin{abstract}
Abstrak
Penelitian yang dilakukan ini merupakan penelitian eksperimen dengan desain penelitian quasi eksperimen. Tujuan dari penelitian ini adalah untuk mengetahui adanya pengaruh perbedaan gaya belajar dan model pembelajaran terhadap hasil belajar kelas VII SMP Negeri 3 Gelumbang. Siswa kelas 8 SMP Negeri 3 Gelumbang merupakan sampel yang digunakan dalam penelitian ini. Sampel penelitian ini berjumlah 53 siswa. Penelitian ini menggunakan uji Anova 2 jalur berbantuan aplikasi SPSS. Uji Prasyarat yang digunakan adalah Uji Shapiro Wilk dan uji Leven Statistic. Nilai Sig. yang didapat untuk uji anova 2 jalurnya adalah 0,517>0,05 sehingga hasil yang kita peroleh adalah : (1) tidak terdapat pengaruh yang signifikan model pembelajaran terhadap hasil belajar siswa; (2) tidak terdapat pengaruh yang signifikan gaya belajar yang digunakan siswa terhadap hasil belajar yang mereka dapatkan; (3) tidak ada interaksi antara gaya belajar dan model pembelajaran terhadap hasil belajar. Hasil yang kta dapat ini disebabkan oleh beberapa faktor seperti : (1) Intrumen yang diujikan tidak mencakup tujuan pembelajaran \& (2) Instrumen yang diberikan bersifat abstrak. Penggunaan instrument yang tepat dan sesuai dapat membantu untuk penelitian lainnya.
\end{abstract}

Kata kunci: gaya belajar; hasil belajar; model pembelajaran.

\begin{abstract}
This research is an experimental research with a quasi-experimental research design. The purpose of this study was to determine the effect of differences in learning styles and learning models on the learning outcomes of class VII SMP Negeri 3 Gelumbang. The 8th grade students of SMP Negeri 3 Gelumbang are the samples used in this study. The sample of this study amounted to 53 students. This study uses a 2-way Anova test assisted by the SPSS application. Prerequisite test used is Shapiro Wilk test and Leven Statistic test. Value of Sig. obtained for the 2-way ANOVA test is $0.517>0.05$ so that the results we get are: (1) there is no significant effect of the learning model on student learning outcomes; (2) there is no significant effect of the learning style used by students on the learning outcomes they get; (3) there is no interaction between learning styles and learning models on learning outcomes. The results we got were caused by several factors such as: (1) The instrument tested did not cover the learning objectives \& (2) The instrument provided was abstract. The use of appropriate and appropriate instruments can help for other research.
\end{abstract}

Keywords: learning styles; learning outcomes; learning models

*Penulis Korespondensi 


\section{JURNAL GANTANG. September 2021; VI(2): 169 - 176 \\ p-ISSN. 2503-0671 \\ e-ISSN. 2548-5547}

\section{Pendahuluan}

Setiap individu manusia memiliki karakteristik masing - masing dalam berbagai hal, seperti halnya dengan belajar sesuatu yang biasa disebut dengan gaya belajar. Gaya Belajar adalah cara setiap orang harus menerima, menyerap, memproses, mengatur dan mengolah informasi yang didapatkan. Kunci keberhasilan siswa dalam belajar adalah penggunaan gaya belajar yang sesuai (Bire, Geradus, Bire, 2014; Papilaya \& Huliselan, 2016). Gaya belajar merupakan cara dimana peserta didik mengumpulkan informasi melalui menghafal, berpikir, dan memecahkan masalah yang berhubungan dengan kepribadian seorang individu yang dipengaruhi oleh sejarah pendidikan dan perkembangannya. Gaya belajar adalah cara individu lebih suka menerima informasi dari lingkungan dan memproses informasi tersebut (Darmawati, 2017). Dalam kata lain, gaya belajar adalah cara seseorang untuk dapat mencerna dan mengelola informasi yang didapatkan sebagai cara untuk mencapai keberhasilaseseorang dalam menerima pembelajaran, menyerap apa yang dipelajari, mengatur, memproses dan mengolah informasi. Terdapat tiga gaya belajar secara umum yaitu penglihatan (visual), pendengaran (auditorial) dan gerakan (kinestetik) (Hartati, 2015).

Menurut Deporter (1999) dan Keefe, (1991) setiap gaya belajar memiliki karakteristik khusus yang membedakan setiap gaya belajar. Siswa dengan gaya belajar penglihatan (visual) lebih mengutamakan indera penglihatan penglihatan mereka daripada indera lainnya dalam sebuah pembelajaran (Bire, dkk, 2014). Siswa yang menggunakan gaya belajar penglihatan (visual) memiliki karakteristik seperti; 1) Kebutuhan untuk melihat sesuatu (informasi/kelas) secara visual untuk mempelajari atau memahaminya; 2) Sensitivitas terhadap warna sangat kuat. 3) Harus memiliki pemahaman yang cukup tentang masalah artistik. 4) Percakapan langsung sulit dilakukan. 5) Merasakan sensitive terhadap suara. 6) Kesulitan mengikuti nasihat lisan; 7) Sering salah mengartikan kata atau frasa (Darmawati, 2017;
Hartati, 2015; Widayanti, 2013). Pada gaya belajar pendengaran (auditorial) mempunyai karakteristik seperti; 1) Siswa dengan gaya belajar ini - semua informasi hanya dapat dipelajari dengan mendengarkan. 2) Kesulitan mengasimilasi informasi tertulis secara langsung. 3) Kesulitan menulis atau membaca. Pada gaya belajar gerakan (kinestetik) memiliki karakter yang sangat khas yaitu selalu menempatkan tangan sebagai pemberi informasi utama untuk mengingatnya.

Gaya belajar mempengaruhi prestasi akademik dan hasil belajar dapat dicapai dengan gaya belajar yang tepat. Belajar merupakan proses dimana peserta didik berusaha untuk mengubah perilaku mereka secara keseluruhan sebagai hasil dari pengalaman peserta didik sendiri berinterasi dengan lingkungan mereka (Nurhasanah \& Sobandi, 2016). Hasil belajar bagi siswa merupakan salah satu tujuan kurikulum sekolah, yang menuntut guru untuk mengetahui, mempelajari dan menerapkan berbagai metode pengajaran (Rijal \& Bachtiar, 2015). Untuk mencapai prestasi siswa (outcome) yang tinggi, guru harus mengajar dan mengajar siswa dengan menggunakan pedagogi yang diperlukan dalam proses pembelajaran di kelas. Sesuai dengan penelitian yang dilakukan (Nasution, 2017) bahwa untuk menjamin adanya hasil belajar yang berkualitas bagi siswa yang dapat diperoleh sebagai hasil dari kurikulum yang berkualitas, guru membutuhkan kemampuan untuk menerapkan metode pengajaran yang sesuai dengan kebutuhan kelas. Meningkatkan hasil belajar siswa di sekolah dapat didorong oleh guru dengan menggunakan metode dan model pengajaran yang tepat seperti mengetahui gaya belajar peserta didik sebagai metodenya dan menggunakan model PBL.

Pembelajaran yang bagus yaitu pembelajaran yang ada interaksi guru dengan siswa, siswa dengan siswa dan sumber belajar. Interaksi ini akan meningkatkan siswa untuk aktif membangun pengetahuan dan memungkinkan pembelajaran menjadi interaktif, inspiratif, menyenangkan, mengasyikkan dan memotivasi 
untuk mencapai kompetensi yang diharapkan (Gokalp, 2013; Nayazik \& Sukestiyarno, 2012; Putra, 2015). Model pembelajaran yang sering diterapkan di Indonesia yaitu model pembelajaran langsung (konvensional), model pembelajaran PBL (Problem based learning), discovery learning, dan model pembelajaran lainnya (Fathurrohman, 2015). Model pembelajaran konvensional dan model PBL terdapat perbedaan, pada pembelajaran konvensional dirancang untuk pengetahuan prosedural dan deklaratif terstruktur dengan baik dan dapat dipelajari langkah demi langkah (Sundawan, 2016). Model PBL dirancang untuk meningkatkan pemahaman siswa tidak sekedar menghafal (Aulya \& Purwaningrum, 2021; Indarwati, dkk, 2014). Tujuan penelitian ini guna untuk mengetahui adanya pengaruh gaya belajar siswa, untuk mengetahui model pembelajaran mana yang lebih baik antara model pembelajaran langsung dengan model pembelajaran PBL dan apakah ada interaksi antara gaya belajar dengan model pembelajaran.

\section{Metode Penelitian}

Penelitian ini merupakan penelitian eksperimen dengan desain quasi Eksperimen. Pada penelitian kali ini terdapat dua kelompok, yaitu model pembelajaran langsung dan PBL serta dikategorikan masing masing menjadi 3 kelompok gaya belajar yaitu siswa dengan gaya belajar penglihatan (visual), pendengaran (auditorial) dan gerakan (kinestetik). Subjek pada penelitian ini adalah siswa kelas 81 dan 82 SMP Negeri 3 Gelumbang yang berjumlah 53 orang. Instrumen yang digunakan berupa RPP, LKPD, soal tes dan angket gaya belajar. Angket gaya belajar digunakan untuk mengetahui gaya belajar siswa sedangkan soal tes digunakan untuk mencari tahu hasil belajar siswa dalam materi yang diajarkan. Uji Normalitas, Uji Homogenitas, dan Uji Anova 2 jalur merupakan teknik analisis data yang digunakan dalam penelitian ini. Hipotesis penelitiannya adalah:

$\mathrm{H}_{0}$ : Tidak ada interaksi antara gaya belajar dan model pembelajaran terhadap hasil belajar.
$\mathrm{H}_{\mathrm{A}}$ : Adanya Interaksi antara gaya belajar dan model pembelajaran terhadap hasil belajar.

Analisis dilakukan dengan bantuan aplikasi SPSS. Untuk penarikan kesimpulan, jika Nilai Signifikansi > 0,05 maka $\mathrm{H}_{0}$ tidak ditolak, dan jika Nilai Signifikansi < 0,05 maka $\mathrm{H}_{0}$ ditolak.

\section{Hasil dan Pembahasan}

Data yang didapat oleh peneliti dalam penelitian ini adalah sebagai berikut:

Tabel 1.

Data statistik penelitian

\begin{tabular}{|c|c|c|c|c|}
\hline \multirow{3}{*}{$\begin{array}{c}\text { Gaya } \\
\text { Belajar }\end{array}$} & \multirow{3}{*}{$\begin{array}{c}\text { Data } \\
\text { Statistik }\end{array}$} & \multicolumn{2}{|c|}{ Model Pembelajaran } & \multirow{3}{*}{$\begin{array}{c}\text { Hasil } \\
\text { Belajar }\end{array}$} \\
\hline & & $\mathrm{A}_{1}$ & $\mathrm{~A}_{2}$ & \\
\hline & & $\begin{array}{c}\text { Prestasi } \\
\text { Siswa } \\
\end{array}$ & $\begin{array}{c}\text { Prestasi } \\
\text { Siswa } \\
\end{array}$ & \\
\hline \multirow{4}{*}{$\mathrm{B}_{1}$} & $\mathrm{~N}$ & 8 & 16 & 24 \\
\hline & $\sum \mathrm{x}$ & 570 & 1180 & 1750 \\
\hline & $\sum x^{2}$ & 43350 & 93050 & 136400 \\
\hline & $\begin{array}{l}\text { Rata- } \\
\text { Rata }\end{array}$ & 71,25 & 73,75 & 72,917 \\
\hline \multirow{4}{*}{$\mathrm{B}_{2}$} & $\mathrm{~N}$ & 5 & 6 & 11 \\
\hline & $\sum \mathrm{x}$ & 280 & 450 & 730 \\
\hline & $\sum \mathrm{x}^{2}$ & 16600 & 35800 & 52400 \\
\hline & $\begin{array}{l}\text { Rata- } \\
\text { Rata }\end{array}$ & 56 & 75 & 66,364 \\
\hline \multirow{4}{*}{$\mathrm{B}_{3}$} & $\mathrm{~N}$ & 10 & 3 & 13 \\
\hline & $\sum \mathrm{x}$ & 715 & 225 & 940 \\
\hline & $\sum \mathrm{x}^{2}$ & 53875 & 17325 & 71200 \\
\hline & $\begin{array}{l}\text { Rata- } \\
\text { Rata }\end{array}$ & 71,5 & 75 & 72,308 \\
\hline \multicolumn{2}{|c|}{$\mathrm{N}$} & 23 & 25 & 48 \\
\hline \multicolumn{2}{|c|}{$\sum \mathrm{x}$} & 1565 & 1855 & 3420 \\
\hline \multicolumn{2}{|c|}{$\sum x^{2}$} & 113825 & 146175 & 260000 \\
\hline \multicolumn{2}{|c|}{ Rata Rata } & 68,043 & 74,2 & 71,25 \\
\hline
\end{tabular}

Data dari Table 1 tersebut selanjutnya diuji terlebih dahulu Normalitas dan Homogenitas nya sehingga didapatkan hasil sebagai berikut: 
JURNAL GANTANG. September 2021; VI(2): 169 - 176

p-ISSN. 2503-0671

e-ISSN. 2548-5547

Uji Normalitas

Tabel 2.

Hasil uji normalitas

\begin{tabular}{ccccccc}
\hline & \multicolumn{3}{c}{ Kolmogorov- } & \multicolumn{3}{c}{ Shapiro-Wilk } \\
\cline { 2 - 7 } & Stat & df & Sig. & Stat & df & Sig. \\
\hline $\begin{array}{c}\text { Lang- } \\
\text { sung }\end{array}$ & 0,151 & 26 & 0,132 & 0,935 & 26 & 0,100 \\
\hline PBL & 0,138 & 26 & $0,200^{*}$ & 0,931 & 26 & 0,080 \\
\hline a. Lilliefors Significance & Correction \\
\hline \\
*. This is a lower bound of the true significance
\end{tabular}

Berdasarkan Tabel 2 diatas, karena data yang kita miliki kurang dari 50 siswa maka kita tinjau pada kolom Shapiro Wilk. Dapat kita dilihat bahwa nilai signifikansi untuk kelas dengan model pembelajaran Langsung adalah 0,100 . Nilai tersebut menunjukkan bahwa hasilnya lebih dari 0,05. Maka dengan nilai signifikansi 0,100 data tersebut berdistribusi normal. Demikian pula dapat kita lihat untuk kelas yang menerapkan model PBL, nilai signifikansinya adalah 0,80 dimana lebih dari 0,05 maka dapat kita katakan bahwa data yang kita miliki berdistribusi normal.

\section{Uji Homogenitas}

Tabel 3.

Hasil uji homogenitas

\begin{tabular}{cccc}
\hline \multicolumn{4}{c}{ Hasil Belajar Matematika } \\
\hline Levene Statistic & df1 & df2 & Sig. \\
\hline 0,16 & 1 & 51 & 0,899 \\
\hline
\end{tabular}

Dilihat dari Tabel 3 diatas, bahwa untuk variabel Hasil belajar nilai Signifikansinya adalah 0,899. Karena nilai signifikansi $0,899>0,05$, maka sebagaimana dasar pengambilan keputusan uji homogenitas dapat disimpulkan bahwa varians data hasil belajar matematika adalah sama atau homogen

Data yang kita dapat berdistribusi normal dan variansnya homogen. Karena hal ini, kita dapat melanjutkan dengan mengunakan uji Anova 2 jalur yang dibantu oleh aplikasi SPSS untuk perhitungannya.

\section{Uji Anova 2 Jalur}

Tabel 4.

Hasil uji anova 2 jalur

\begin{tabular}{|c|c|c|c|c|c|}
\hline \multicolumn{6}{|c|}{ Test of Between Subjects Effects } \\
\hline \multicolumn{6}{|c|}{ Variabel Terikat : Hasil Belajar } \\
\hline Source & $\begin{array}{l}\text { Type III } \\
\text { Sum of } \\
\text { squares }\end{array}$ & $d f$ & $\begin{array}{c}\text { Mean } \\
\text { Square }\end{array}$ & $F$ & Sig. \\
\hline $\begin{array}{c}\text { Corrected } \\
\text { Model }\end{array}$ & $\begin{array}{c}1360,76 \\
5^{\mathrm{a}} \\
\end{array}$ & 5 & 272,153 & $\begin{array}{c}0,78 \\
0 \\
\end{array}$ & $\begin{array}{c}0,57 \\
0 \\
\end{array}$ \\
\hline Intercept & $\begin{array}{c}188411, \\
528 \\
\end{array}$ & 1 & $\begin{array}{c}188411, \\
528\end{array}$ & $\begin{array}{l}540 \\
023\end{array}$ & $\begin{array}{c}0,00 \\
0\end{array}$ \\
\hline $\begin{array}{c}\text { Model } \\
\text { Pembelajaran } \\
\end{array}$ & 578,777 & 1 & 578,777 & $\begin{array}{c}1,65 \\
9 \\
\end{array}$ & $\begin{array}{c}0,20 \\
5 \\
\end{array}$ \\
\hline Gaya Belajar & 365,06 & 2 & 182,530 & $\begin{array}{c}0,52 \\
3 \\
\end{array}$ & $\begin{array}{c}0,59 \\
6 \\
\end{array}$ \\
\hline $\begin{array}{c}\text { Model } \\
\text { Pembelajaran } \\
* \text { Gaya } \\
\text { Belajar } \\
\end{array}$ & 466,988 & 2 & 233,494 & $\begin{array}{l}0,66 \\
9\end{array}$ & $\begin{array}{c}0,51 \\
7\end{array}$ \\
\hline Error & 15002,5 & 43 & 348,895 & & \\
\hline Total & 264225 & 49 & & & \\
\hline $\begin{array}{c}\text { Corrected } \\
\text { Total } \\
\end{array}$ & $\begin{array}{c}16363,2 \\
65 \\
\end{array}$ & 48 & & & \\
\hline
\end{tabular}

Berdasarkan Tabel 4, dapat diperoleh hasil sebagai berikut :

\section{Corrected Model}

Dari koresi model ini kita dapat mengetahui seberapa besar pengaruh variabel bebas terhadap variabel terikat. Dari tabel diatas bisa kita lihat berdasarkan nilai signifikansinya, $0,570>0,05$ berarti hasil yang diperoleh tidak valid.

\section{Intercept}

Nilai intercept dalam hal ini merupakan nilai siswa pada variabel nilai yang berkontribusi pada nilai itu sendiri tanpa dipengaruhi oleh variabel terikat, artinya perubahan nilai untuk variabel bebas tidak ada pengaruhnya oleh variabel terikat. Dari tabel diatas dapat kita lihat berdasarkan nilai signifikansinya $0,000<0,05$ yang mengartikan nilai Intercept ini berkontribusi secara signifikan.

\section{Model Pembelajaran}

Ada Pengaruh atau tidak suatu model pembelajaran terhadap hasil belajar siswa ditandai dari nilai signifikan yang dapat kita lihat dari tabel di atas bahwa nilai signifikansi 0,205 dimana $0,205>0,05$ yang berarti Model 
Pembelajaran tidak terlalu berpengaruh signifikan terhadap hasil belajar siswa.

\section{Gaya Belajar}

Ada Pengaruh atau tidak suatu gaya belajar terhadap hasil belajar siswa ditandai dari nilai signifikan, dari tabel di atas nilai sig 0,596 dimana $0,596>0,05$ yang berarti Gaya Belajar tidak terlalu berpengaruh signifikan terhadap hasil belajar siswa.

\section{Model Pembelajaran * Gaya Belajar}

Uji ini bertujuan untuk mengetahui apakah ada hubungan yang signifikan antara 2 faktor, dalam kasus ini kita akan menguji ada atau tidaknya interaksi antara model pembelajaran dengan gaya belajar siswa.

Hipotesis penelitian ini adalah:

$\mathrm{H}_{0}$ : tidak ada interaksi antara model pembelajaran dan gaya belajar siswa terhadap hasil belajar siswa.

$\mathrm{H}_{\mathrm{A}}$ : ada interaksi antara model pembelajaran dan gaya belajar siswa terhadap hasil belajar siswa.

Untuk pengambilan keputusan, hasil yang kita perolah memenuhi : jika $\mathrm{F}$ hitung $<\mathrm{F}$ tabel atau nilai sig > 0,05, maka tidak ditolak $\mathrm{H} 0$ dan jika $\mathrm{F}$ hitung $>\mathrm{F}$ tabel atau nilai sig $<0,05$, maka $\mathrm{H} 0$ ditolak.

Keputusan yang data kita ambil dari tabel di atas terlihat bahwa nilai $\mathrm{F}$ hitung 0,669 dan $\mathrm{F}$ tabel 3,214 atau nilai signifikan yang di peroleh dari tabel di atas sebesar 0,517. Jadi kesimpulan yang dapat kita ambil adalah tidak ada interaksi antara model pembelajaran dan gaya belajar siswa terhadap hasil belajar siswa.

Berdasarkan analisis data yang sudah kita dapatkan, maka dapat kita didapat bahwa:

1. Dari penelitian yang dilakukan tidak ada pengaruh yang signifikan model pembelajaran yang diterapkan terhadap hasil belajar

2. Dari penelitian yang dilakukan tidak ada pengaruh yang signifikan gaya belajar siswa terhadap hasil belajar

3. Dari penelitian yang dilakukan tidak ada interaksi antara model pembelajaran dan gaya belajar siswa terhadap hasil belajar.
Model Pembelajaran digunakan sebagai pedoman untuk tercapainya tujuan pembelajaran yang didalamnya terdapat strategi, teknik, metode, bahan, media dan alat penilaian pembelajaran (Affandi, Chamalah, \& Wardani, 2013). Penggunaan model pembelajaran sangat menentukan keberhasilan siswa dibandingkan variabel lain (Nurdin, Nayan, \& Risnawati, 2020). Dalam pemilihan model pembelajaran guru diminta untuk dapat menyesuaikan dengan materi yang diajarkan. Pada penelitian yang dilakukan oleh Zuriati (2020) memuat pernyataan bahwa model pembelajaran Problem Based Learning berpengaruh untuk meningkatkan hasil belajar siswa.

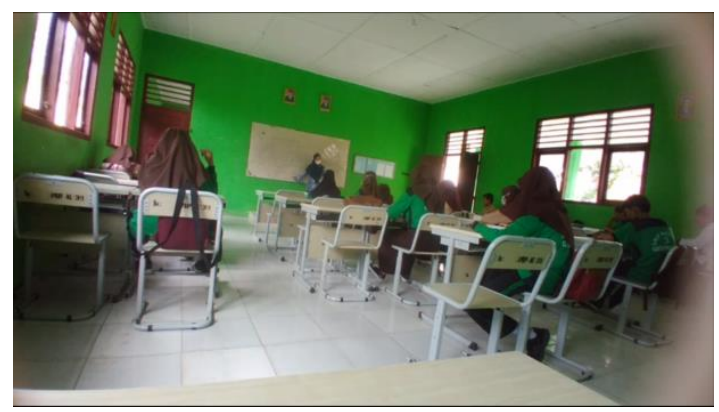

Gambar 1 Pembelajaran dengan model konvensional

Dalam penelitian kali ini, kelas 8.1 adalah kelas kontrol dimana mereka belajar dengan menggunakan model pembelajaran konvensional. Pembelajaran dilakukan dengan membagi 2 kelas 8.1 yaitu kelas 8.1A dan 8.1B sesuai dengan protokol kesehatan yang dilakukan pada masa pandemi seperti sekarang ini. Tetapi pembelajaran proses yang dilakukan tetaplah sama dengan menggunakan model pembelajaran konvensional. Poses pembelajaran yang dilakukan seperti : Guru menyampaikan materi, guru memberikan Tanya-jawab, siswa menjawab pertanyaan guru dan yang terakhir guru memberikan soal berupa tes. Setelah siswa selesai mengerjakan soal, maka pembelajaran selesai dan ditutup dengan doa.

Selanjutnya, untuk kelas eksperimen dalam penelitian ini adalah kelas 8.2. Sama halnya dengan kelas 8.1, kelas ini juga dibagi menjadi 2 yaitu 8.2A dan 8.2B tetapi untuk proses pembelajaran yang dilakukan sama. 


\section{JURNAL GANTANG. September 2021; VI(2): 169 - 176 \\ p-ISSN. 2503-0671 \\ e-ISSN. 2548-5547}

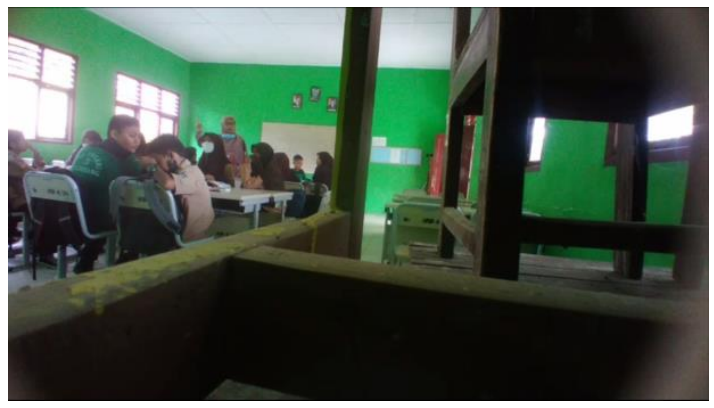

Gambar 2 Pembelajaran dengan model PBL

Kelas eksperimen ini menerapkan model pembelajaran PBL dengan menggunakan LKPD serta soal berupa tes. Penyelesaian lembar kerja diselesaikan dengan cara berkelompok yang pada akhir nya mereka akan mempresentasikan hasil yang sudah mereka kerjakan. Pada akhir pembelajaran, mereka akan diberikan soal berupa tes tertulis untuk mengetahui seberapa paham mereka dalam memahami pembelajaran yang dilakukan oleh guru.

Terdapat perbedaan dalam pembelajaran dengan model pembelajaran konvensional dan model PBL. Pada pembelajaran konvensional dirancang untuk pengetahuan prosedural dan deklaratif terstruktur dengan baik dan dapat dipelajari langkah demi langkah (Sundawan, M, 2016). Model PBL dirancang untuk meningkatkan pemahaman siswa tidak sekedar menghafal (Aulya \& Purwaningrum, 2021; Indarwati, dkk, 2014).

Menurut Anjar (2013) langkah - langkah pembelajaran Konvensional sebagai berikut:

a. Guru menyampaikan tujuan.

b. Guru menyampaikan informasi

c. Guru mengecek pemahaman dan memberikan umpan balik.

d. Guru memberikan kesempatan latihan lanjutan.

Langkah langkah model pembelajaran PBL seperti yang dijelaskan oleh Lestari (2020) adalah: (1) memberikan pertanyaan kepada siswa, (2) memberikan masalah yang harus dipecahkan oleh siswa, (3) mengorganisasikan peserta didik, (4) membimbing penyelidikan dalam kelompok untuk menyelesaikan masalah, mengembangkan serta mempresentasikan hasil diskusi. Dalam penelitian yang dilakukan oleh peneliti, telah menerapkan pembelajaran sesuai dengan langkah langkah dalam pembelajaran dengan model PBL.

Peneliti memberikan Instrumen berupa LKPD dengan beberapa tujuan pembelajaran. Setelah pembelajaran selanjutnya dilakukan tes untuk mengetahui hasil belajar yang didapat oleh siswa dengan menerapkan moel pembelajaran PBL. Menurut Khadir (2015), soal tes dikatakan baik jika soal tersebut dibuat sesuai dengan Indikator yang diharapkan. Instrumen tes yang dibuat oleh peneliti bersifat abstrak dan tidak sesuai dengan tujuan pembelajaran dan indikator yang sudah dibuat. Hasil penelitian yang dilakukan menjadi tidak ada pengaruh serta tidak ada interaksi antara model pembelajaran dan gaya belajar terhadap hasil belajar.

\section{Kesimpulan}

Dari penelitian ini, ada 3 kesimpulan yang didapat yaitu : (1) tidak terdapat pengaruh yang signifikan model pembelajaran yang diterapkan oleh guru terhadap hasil belajar yang didapat oleh siswa. (2) tidak terdapat pengaruh yang signifikan gaya belajar siswa terhadap hasil belajar yang diperoleh. (3) tidak terdapat interaksi antara model pembelajaran dan gaya belajar siswa terhadap hasil belajar. Salah satu faktor yang menyebabkan ini adalah penggunaan instrumen dan proses pembelajaran yang dianggap tidak sesuai. Soal tes tidak sesuai dengan indikator penilaian sehingga membuat tidak ada pengaruh suatu model pembelajaran dan gaya belajar terhadap hasil belajar serta tidak ada interaksi antara model pembelajaran dan gaya belajar terhadap hasil belajar. Penelitian kedepannya diharapkan pengunaan instrument diperhatikan secara tepat sehingga hasil yang didapat bisa lebih maksimal.

\section{Ucapan Terimakasih}

Peneliti mengucapkan terima kasih kepada seluruh subject yang telah bersedia menjadi sampel pada penelitian ini. Artikel ini merupakan luaran dari mata kuliah Statistika Multivariat, Program Studi Pendidikan Matematika, Universitas Sriwijaya, Semester Ganjil Tahun Ajaran 2021/2022. 


\section{Referensi}

Affandi, M., Chamalah, E., \& Wardani, O. P. (2013). Model dan metode pembelajaran di sekolah. Semarang.

Anjar. (2013). Model dan sintak pembelajaran konvensional. Retrieved from http/www.wawasanpendidikan.com/2013/0 8/model-dan-sintaks-pembelajarankonvensional.html.

Aulya, R., \& Purwaningrum, J. P. (2021). Pengaruh model pembelajaran pbl berbantuan alat peraga dalam peningkatan kemampuan penalaran matematis. Jurnal MathEdu (Mathematics Education Journal), 4(3), 72-77.

Bire, A. L., Geradus, U., \& Bire, J. (2014). Pengaruh gaya belajar visual, auditorial, dan kinestetik terhadap prestasi belajar siswa. Jurnal Kependidikan: Penelitian Inovasi Pembelajaran, 44(2), 167-174. https://doi.org/10.21831/jk.v44i2.5307

Darmawati, J. (2017). Pengaruh motivasi belajar dan gaya belajar terhadap prestasi belajar ekonomi siswa SMA Negeri di kota Tuban. Jurnal Ekonomi Pendidikan Dan Kewirausahaan, $\quad 1(1), \quad 79$. https://doi.org/10.26740/jepk.v1n1.p79-90

Deporter, B. (1999). Quantum learning. Bandung: Bandung: Kaifa.

Fathurrohman, M. (2015). Model - model pembelajaran. Jogjakarta: Ar-Ruzz Media.

Gokalp, M. (2013). The effect of student's learning styles to their academic success. Creative Education, 4(10).

Hartati, L. (2015). Pengaruh gaya belajar dan sikap siswa pada pelajaran matematika terhadap hasil belajar matematika. Formatif: Jurnal Ilmiah Pendidikan MIPA, 3(3), 224235.

https://doi.org/10.30998/formatif.v3i3.128

Indarwati, D., Wahyudi, W., \& Ratu, N. (2014). Peningkatan kemampuan pemecahan masalah matematika melalui penerapan problem based learning untuk siswa kelas $\mathrm{V}$ SD. Satya Widya, 30(1), 17. https://doi.org/10.24246/j.sw.2014.v30.i1.p 17-27

Keefe, J. W. (1991). Learning style: Cognitive and thingking skills. Reston, VA: National Association of Secondary School Principals.

Khadir, A. (2015). Menyusun dan menganalisis tes hasil belajar. Jurnal Al-Ta'dib, 70-81.

Lestari, P. A., Slameto, \& Radia, E. H. (2018). Penerapan PBL (Problem Based Learning) berbantuan media papan catur untuk meningkatkan hasil belajar matematika kelas 4 SD. Jurnal Pendidikan Dasar PerKhasa, 53-62.

Nasution, M. K. (2017). Penggunaan metode pembelajaran dalam peningkatan hasil belajar siswa. STUDIA DIDAKTIKA: Jurnal Ilmiah Bidang Pendidikan, 11(1), 9-16.

Nayazik, A., \& Sukestiyarno. (2012). Pembelajaran matematika model ideal problem solving dengan teori pemrosesan informasi untuk pembentukan pendidikan karakter dan pemecahan masalah materi dimensi tiga kelas X SMA. PYTHAGORAS: Jurnal Pendidikan Matematika, 7(2), 1-8. https://doi.org/10.21831/pg.v7i2.4778

Nurdin, E., Nayan, D. N., \& Risnawati. (2020). Pengaruh pembelajaran model Creative Problem Solving (CPS) terhadap kemampuan berpikir kritis ditinjau dari kemampuan awal matematis siswa Sekolah Menengah Atas. Jurnal Gantang, 39-49.

Nurhasanah, S., \& Sobandi, A. (2016). Minat belajar sebagai determinan hasil belajar siswa. Jurnal Pendidikan Manajemen Perkantoran, $\quad 1(1), \quad 128$. https://doi.org/10.17509/jpm.v1i1.3264

Papilaya, J. O., \& Huliselan, N. (2016). Identifikasi gaya belajar mahasiswa. Jurnal Psikologi Undip, 15(1), 56. https://doi.org/10.14710/jpu.15.1.56-63

Putra, F. G. (2015). Eksperimentasi model pembelajaran kooperatif tipe Teams Games Tournament (TGT) berbantuan software Cabri 3D di tinjau dari kemampuan koneksi matematis siswa. Al-Jabar: Jurnal Pendidikan Matematika, 6(2), 143-154. 
JURNAL GANTANG. September 2021; VI(2): 169 - 176

p-ISSN. 2503-0671

e-ISSN. 2548-5547

https://doi.org/10.24042/ajpm.v6i2.43

Rijal, S., \& Bachtiar, S. (2015). Hubungan antara sikap, kemandirian belajar, dan gaya belajar dengan hasil belajar kognitif siswa. Jurnal Bioedukatika, $3(2), \quad 15$. https://doi.org/10.26555/bioedukatika.v3i2. 4149

Sundawan, M, D. (2016). Perbedaan model pembelajaran konstruktivisme dan model pembelajaran langsung. Jurnal Logika, XVI(1), 1-11.

Widayanti, F. D. (2013). Pentingnya mengetahui gaya belajar siswa dalam kegiatan pembelajaran di kelas. Erudio Journal of Educational Innovation, 2(1).

Zuriati, E., \& Astimar, N. (2020). Peningkatan hasil belajar pada pembelajaran tematik terpadu menggunakan model problem based learning di kelas IV SD (studi literatur). Jurnal Pendidikan Tambusai, 4(3), 11711182.

https://doi.org/https://doi.org/10.31004/jpta m.v4i3.684 